\title{
Phosphorus Recycling from Wastes
}

\author{
Ketil Haarstad, John Bavor* \\ Nibio, Department of Urban Greening and Environmental Engineering, Western Sydney University, Richmond, NSW, Australia \\ Email: *ketil.haarstad@nibio.no
}

How to cite this paper: Haarstad, K. and Bavor, J. (2017) Phosphorus Recycling from Wastes. Journal of Environmental Protection, 8, 831-843.

https://doi.org/10.4236/jep.2017.88052

Received: May 30, 2017

Accepted: July 11, 2017

Published: July 14, 2017

Copyright () 2017 by authors and Scientific Research Publishing Inc. This work is licensed under the Creative Commons Attribution International License (CC BY 4.0).

http://creativecommons.org/licenses/by/4.0/ (c) (i) Open Access

\begin{abstract}
The plant phosphorus (P) uptake by Italian ryegrass using organic wastes such as sewage sludge, biochar, composted sewage sludge and spent wetland filters as fertilizer was investigated in pot experiments after manipulating the wastes $\mathrm{pH}$ by mixing with other wastes giving acidification by acetic acid and compost leachate, and liming by concrete waste and lime. Pots with no fertilizer and with mineral fertilizer served as control. Available $\mathrm{P}$ was measured both with passive diffuse gradient thin film (DGT) samplers and by P uptake in the grass. The $\mathrm{pH}$ in the treated waste was about 4 in the acid treatment, and more than 11 in the high $\mathrm{pH}$ treatment. The $\mathrm{pH}$ in the pot during the grass production was adjusted to normal levels. The $\mathrm{P}$ uptake increased up to $56 \%$ after $\mathrm{pH}$ treatment of the waste. The $\mathrm{P}$ uptake responded both to the high and low $\mathrm{pH}$ treatments, probably due to the prevalence of different $\mathrm{P}$ species. The more extreme $\mathrm{pH}$ treatments gave the highest uptake. The DGT uptake gave the same broad picture in the pots fertilized with biochar but not in pots with sludge, and, also, without the separation between high and low treatments. The passive samplers correlated relatively well with the measured grass uptake. A principal component (PCA) analysis showed that the $\mathrm{P}$ uptake as measured by the DGT correlated with $\mathrm{P}$, potassium $(\mathrm{K})$ and silicon $(\mathrm{Si})$ concentrations, at to a lower degrade with iron $(\mathrm{Fe})$ and lead $(\mathrm{Pb})$, and was uncorrelated with nickel $(\mathrm{Ni})$ and cupper $(\mathrm{Cu})$. In summary we can say that the $\mathrm{pH}$ treatment of the different organic wastes increased the plant $\mathrm{P}$ availability. The smallest increase was in the wetland filter that also had the lowest P total uptake. Also the lupin treatment increased the plant $\mathrm{P}$ uptake.
\end{abstract}

\section{Keywords}

Organic Waste, Sewage Sludge, Composted Sludge, Biochar, Wetland Filters, Waste Mixing, $\mathrm{pH}$ Treatment, Phosphorus Plant Uptake

\section{Introduction}

Phosphorus (P) is an essential and irreplaceable factor in food production. As 
the world $\mathrm{P}$ resources are limited, the recycling of $\mathrm{P}$ in the food web becomes more and more important. The $\mathrm{P}$ content in soil is generally too low to sustain agricultural production. This is especially the case in Australia [1]. Soil P can be separated into 5 categories, 1) plant available mineral $\mathrm{P}$ as phosphate ions, 2) organic $\mathrm{P}, 3$ ) adsorbed $\mathrm{P}, 4)$ aluminum (Al) and Fe precipitated phosphates and 5) primary mineral $P$ (mainly apatite), the latter three not directly plant available [2]. Unlike nitrate, which readily moves in soil towards the roots via both mass flow and diffusion, phosphate is immobile. Mass flow typically delivers as little as $1 \%-5 \%$ of a plant's $\mathrm{P}$ demand, and the amount intercepted by growing roots is only half of that [3].

Lowering the $\mathrm{pH}$ or increasing the $\mathrm{Al}$ concentration makes $\mathrm{P}$ precipitate as $\mathrm{AlPO}_{4}$, similar to the precipitation of $\mathrm{Al}(\mathrm{OH})_{3}$. In calcium (Ca) rich soil with high $\mathrm{pH}$ levels $\mathrm{P}$ precipitates as hardly water soluble $\mathrm{Ca}$-compounds such as e.g. hydroxyapatite, fluorapatite and chlorapatite [4] (Wang \& Li, 2010). Work in the Nordic countries has shown a relatively high accumulation of $\mathrm{P}$ in peat soils that received treated sewage or industrial effluents for many years [5]. The best immobilization happened in peat that had received effluent that had been treated with $\mathrm{FeCl}_{2}$ or $\mathrm{Al}$ precipitation agents as part of their treatment before discharge. Investigations in Scandinavian wetlands showed a content of $\mathrm{P}$ in filters of up to $7500 \mathrm{mg} / \mathrm{kg}$ dry matter [6]. The uptake of $\mathrm{P}$ in ryegrass pot experiments was, however, low after some years of operation, just 3\% of the P applied. In filters saturated with $\mathrm{P}$ as sodium phosphate, the average uptake increased to $24 \%$, and $37 \%$ when applied as calcium phosphate fertilizer.

The reuse of $\mathrm{P}$ from used wetland filter media showed that the $\mathrm{P}$ was less available than $\mathrm{P}$ from phosphate fertilizer for small plants with limited root growth. For second and third harvest of well-developed grassland, the wetland filters and mineral fertilizers had almost the same fertilization effect [6] [7]. In addition, the wetland filters may have a liming effect, which increases the availability of phosphorus in acidic soils. The adding of simple organic acids to soil reduced $\mathrm{P}$ retention [8]. Wetlands becoming anaerobic will release some of its retained P [9], especially if it is adsorbed to Fe. Some plant species such as Proteaceae, orlupins, specialize in utilizing phosphorous in P-depleted soils [1]. P in soil transfers to the roots by mass flow and diffusion, the latter being very low compared to other nutrients. There is an urgent need to develop crops that efficiently utilize inorganic soil $\mathrm{P}(\mathrm{Pi})$ by using plants that use root exudates [1].

$\mathrm{Fe}$ - and $\mathrm{Al}$ bound phosphate is more available when the $\mathrm{pH}$ in the soil is above 6.5 , as is nitrogen $(\mathrm{N})$, potassium $(\mathrm{K})$, sulphur $(\mathrm{S})$ and magnesium $(\mathrm{Mg})$, whereas Fe and mangan $(\mathrm{Mn})$ are more available at lower $\mathrm{pH}[6]$.

Diffuse Gradient Thin-films (DGTs) can be used to predict plant response to $P$ [10] [11] [12]. The DGT effective concentration, which is lower than the true pore water concentration, was to be $10 \%$ to $50 \%$ of the $\mathrm{P}$ solute in soil with low and high P-AL [13].

This project looks at reclaiming $\mathrm{P}$ from waste from a waste handler's perspective, by mixing different ready available waste fractions; Cantreatment of the 
waste materials by changing their $\mathrm{pH}$ improve the plant $\mathrm{P}$ availability? Is passive sampling a good way to model plant $\mathrm{P}$ availability using waste products as fertilizer?

\section{Methods}

\subsection{The Materials}

Sewage sludge was obtained from Nordre Follorenseanlegg in Ski, Norway. The plant includes a secondary treatment with chemical flocculation and nitrogen removal, using $\mathrm{Fe}$ and $\mathrm{Al}$ based coagulants in addition to polymers. The sludge used in the experiment had been anaerobically stabilized and stored outdoors for several months (Figure 1).

The $\mathrm{pH}$ obtained during treatment is shown in Figure 2. The $\mathrm{pH}$ in the sludge and biochar varies between 6.3 and 9.9, the highest in the biochar produced from wood. Compost leachate is acidic with a $\mathrm{pH}$ of close to 4 , and concrete waste is very basic with a $\mathrm{pH}$ of 11.5. Treatments with low $\mathrm{pH}$ received compost

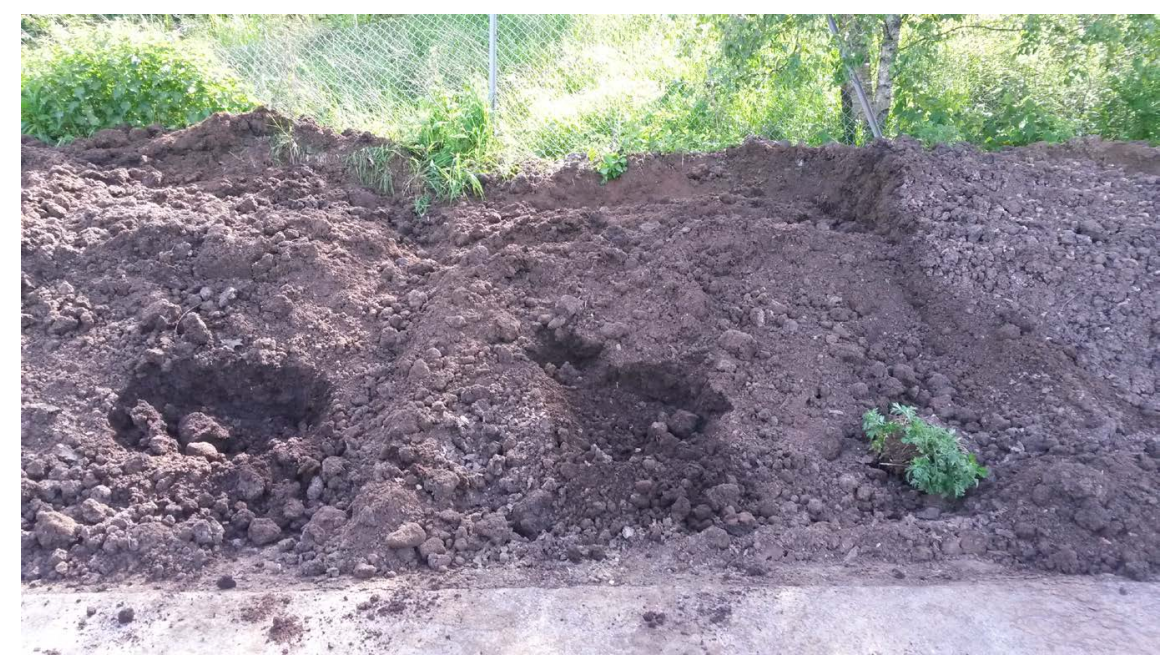

Figure 1. Sewage sludge.

\section{$\mathrm{pH}$ in materials}

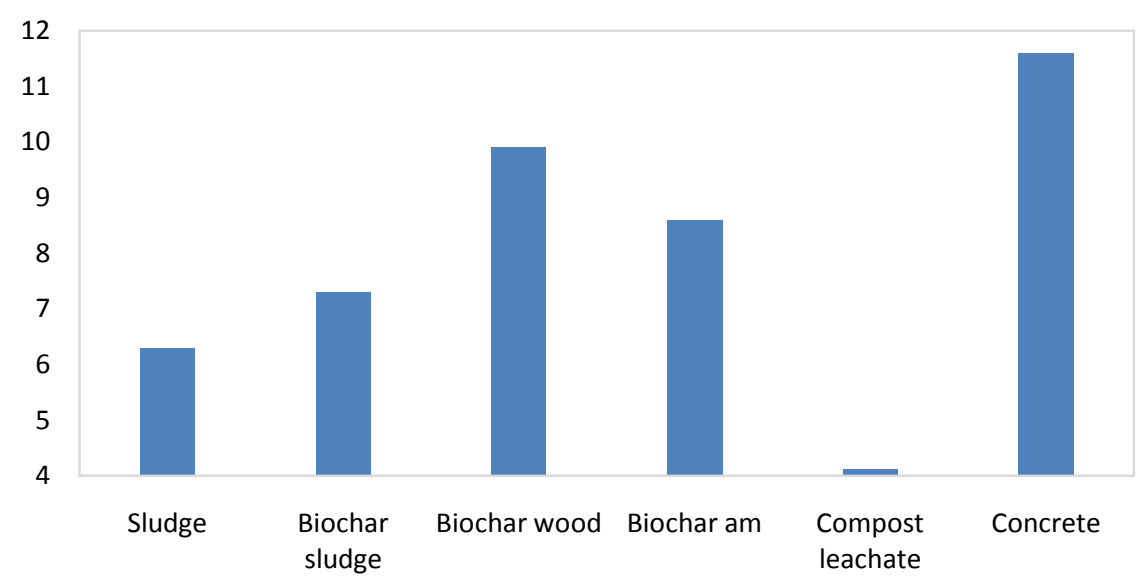

Figure 2. $\mathrm{pH}$ in the waste materials. 
leachate at low and high dosage. Treatments with high $\mathrm{pH}$ received concrete dust in a similar way. The $\mathrm{pH}$ in the low $\mathrm{pH}$ treatment was 4.8 and 4.7 with high and low dosage, respectively, and 5.1 and 4.9 in the biochar, and the high $\mathrm{pH}$ treatment $\mathrm{pH}$ was 9.9 and 11.1 for the sludge, and 11.9 and 11.5 for the biochar. High level included a mix of waste and biochar/concrete at a ratio of 1:2, while low level at ratio 1:1.

The biochar is from Sonnenerde and consisted of two types, mixed together on a 50/50 weight basis (Figure 3). The $\mathrm{P}$ rich biochar was produced from sewage sludge, the low $\mathrm{P}$ biochar was made from wood.

Figures 4-9 and Table 1 characterize the waste materials. The sludge has some total-P but is low in phosphate probably because they are mainly $\mathrm{Al}$ and $\mathrm{Fe}$ precipitates, the biochar from sludge is rich in $\mathrm{P}$, most of it as phosphate (Figure 4). The concrete waste does not contain any P. Biochar made from sludge has the highest content of total-P, followed by sewage sludge (Figure 4). Composted

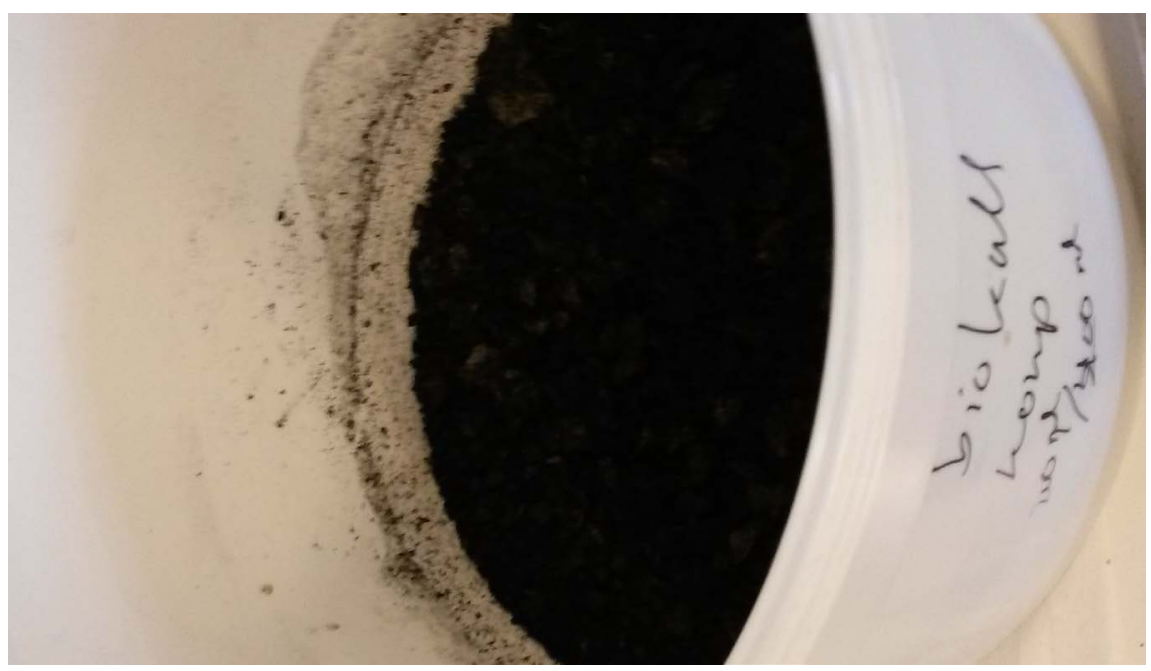

Figure 3. Biochar.

$P$

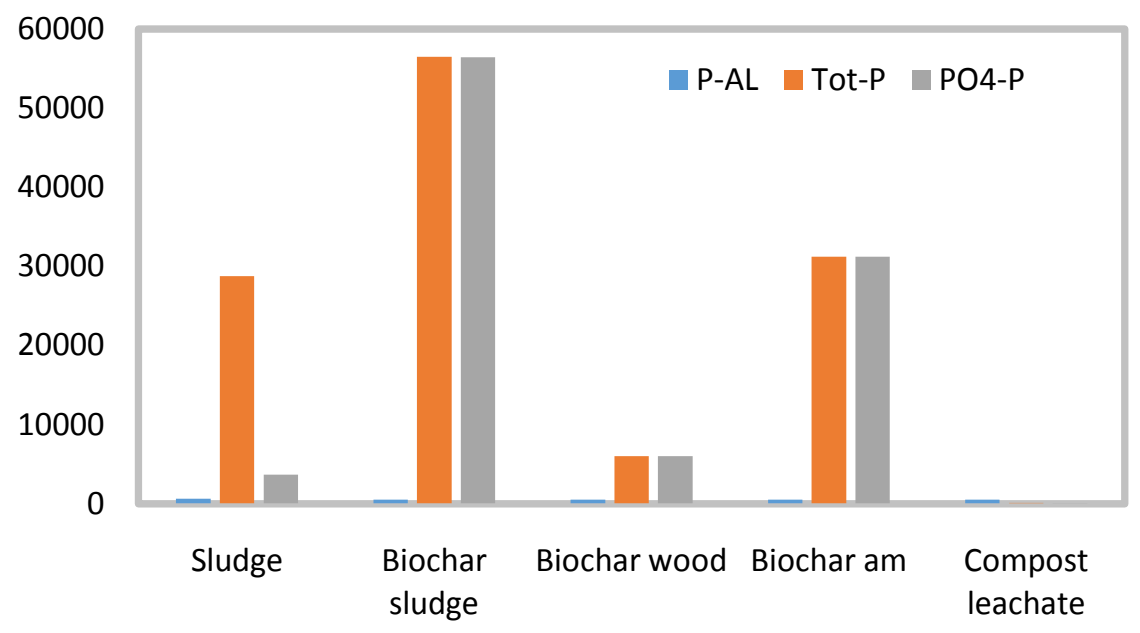

Figure 4. $\mathrm{P}$ in the waste materials. 


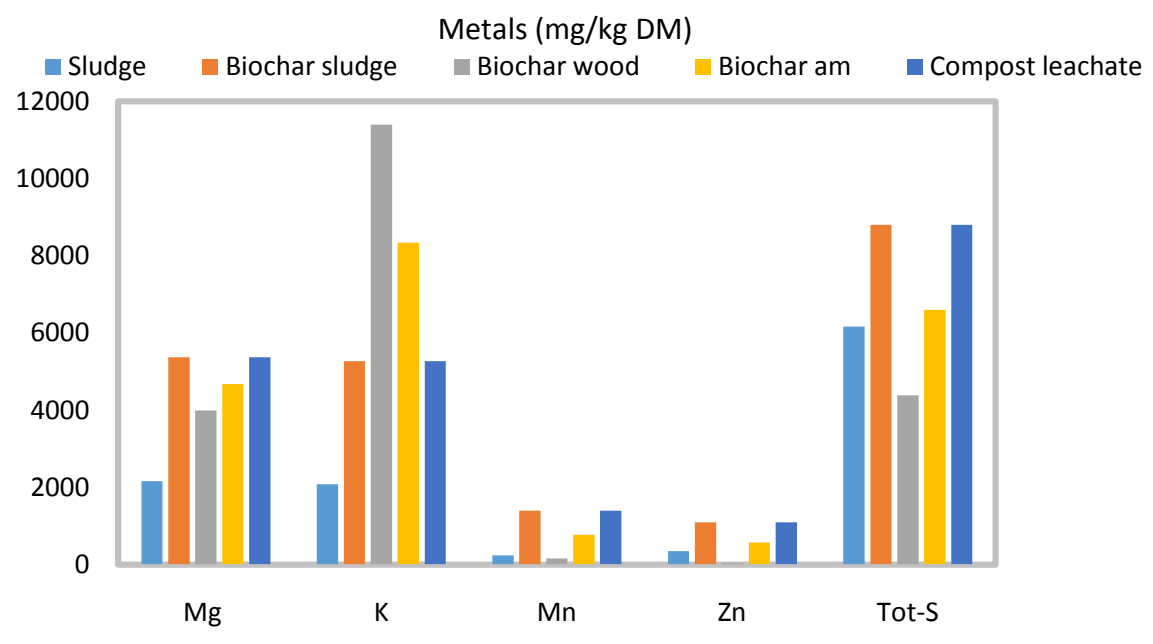

Figure 5. Metals and Sulphur in the waste materials.

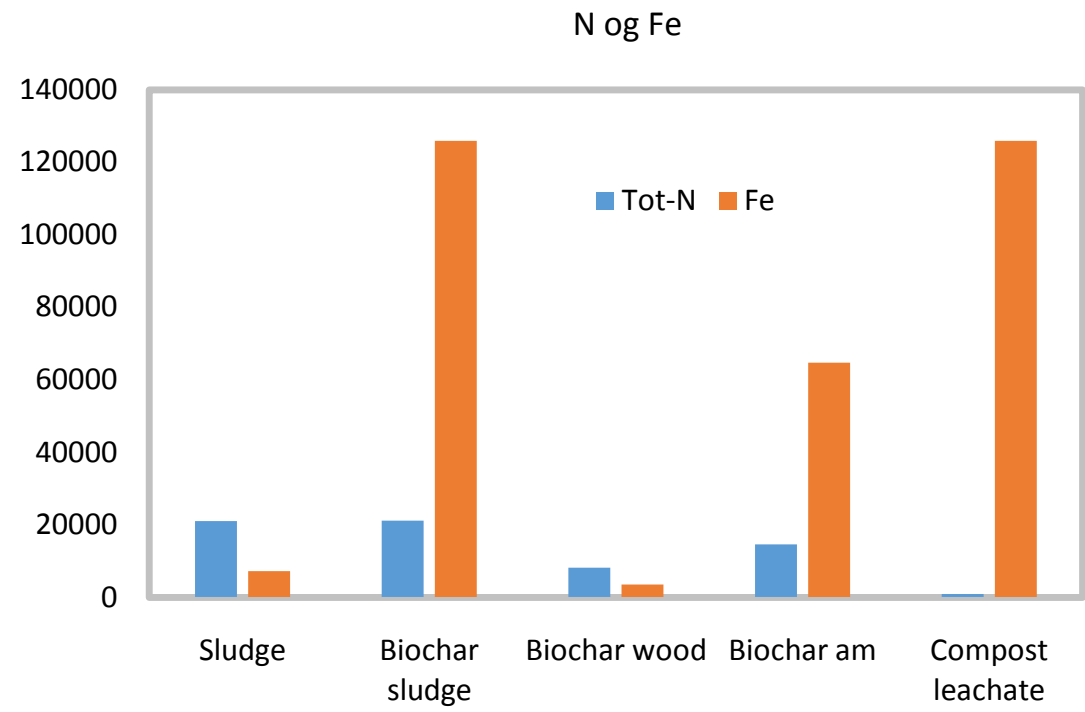

Figure 6. $\mathrm{N}$ and $\mathrm{Fe}$ in the waste materials.

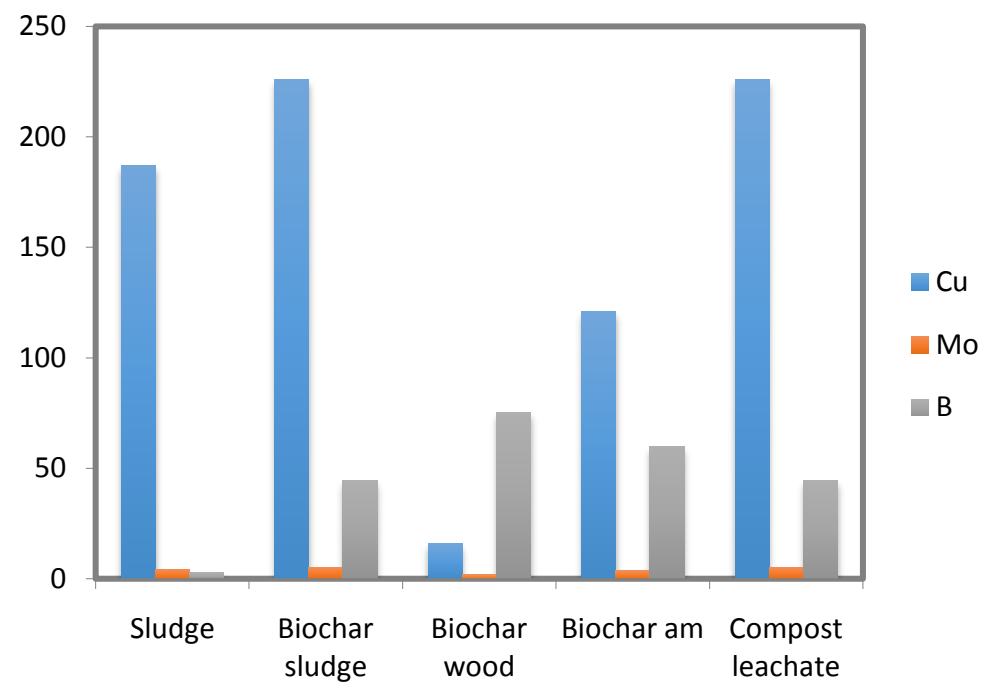

Figure 7. Minor nutrients in the waste materials. 


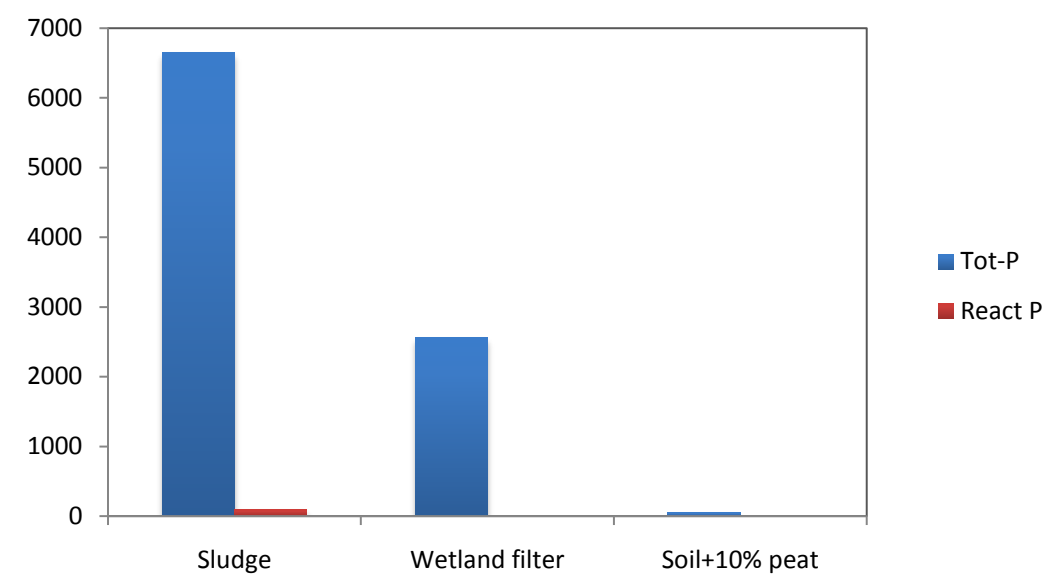

Figure 8. $\mathrm{P}$ in the composted sludge and wetland filter ( $\mathrm{mg} / \mathrm{kg} \mathrm{DM})$.

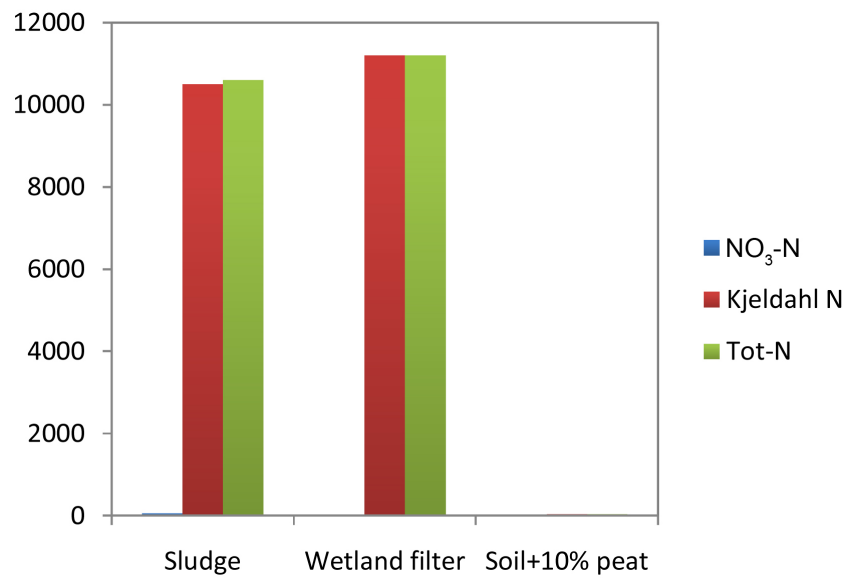

Figure 9. $\mathrm{N}$ in the composted sludge and wetland filter $(\mathrm{mg} / \mathrm{kg}$ DM).

Table 1. Characterization of the waste materials and soil/peat mix (in $\mathrm{mg} / \mathrm{kg}$ dry matter except TOC in \%).

\begin{tabular}{cccc}
\hline & Composted Sludge & Wetland filter & Soil+10\% peat \\
\hline Tot-P & 6650 & 2560 & 56 \\
React P & 94.8 & 1 & $<0.1$ \\
$\mathrm{NO}_{3}-\mathrm{N}$ & 59.3 & 0.5 & $<0.1$ \\
$\mathrm{Kjeldahl-N}$ & 10,500 & 11,200 & 40 \\
$\mathrm{Tot}-\mathrm{N}$ & 10,600 & 11,200 & 40 \\
$\mathrm{SO}_{4}$ & 1550 & 160 & 20 \\
$\mathrm{Ca}$ & 16,900 & 1410 & 130 \\
$\mathrm{Mg}$ & 3870 & 950 & $<50$ \\
$\mathrm{~K}$ & 6440 & 950 & 130 \\
$\mathrm{Fe}$ & 24,000 & 26,600 & 1400 \\
$\mathrm{Mg}$ & 312 & 968 & $<5$ \\
$\mathrm{Zinc}$ & 254 & 81 & $<5$ \\
$\mathrm{TOC}$ & 13.2 & 8 & 0.25 \\
$\mathrm{C} / \mathrm{N}$ & 12 & 7 & 63 \\
$\mathrm{Fe} / \mathrm{P}$ & 3.6 & 10.4 & 25 \\
\hline
\end{tabular}


sludge has a content of total-P ten times lower than biochar (Table 1). Biochar made from wood is high in potassium (Figure 5).

The second part of the experiment used commercial sewage sludge compost and wetland filter as fertilizer (Table 1). Both materials contain a lot of $\mathrm{P}$ but the amount of reactive $\mathrm{P}$ is low. The fertilization was the same as in the first experiment.

The ratio between iron and phosphorus is said to be important for plant $\mathrm{P}$ availability and should not be too high. Plant $\mathrm{P}$ uptake was significantly higher when the $\mathrm{Fe} / \mathrm{P}$ ratio was 1.6 compared to 9.8 according to [14]. The sewage sludge had a favorable ratio of 0.3 , the biochar 2.2 and the other materials more unfavorable with ratios at 3.6 and 10.4 (Table 1).

\subsection{The Experiments}

The experiments were carried out with Italian ryegrass (Loliummultiflorum) in 3 liter plastic pots (Figure 10) filled with sand with $10 \%$ peat as a source for organic matter, while the DGT pots were 1 liter and filled with identical materials. The pots were fertilized with $60 \mathrm{~g}$ phosphate and $300 \mathrm{~g} \mathrm{~N}$, except for unfertilized control pots. $\mathrm{N}$ and $\mathrm{K}$ were also supplied at the two intermediate harvests, but at a lower rate. The water content of the pots was kept at maximum $90 \%$ of field capacity by hand irrigation over 76 days. The harvests from the pots with sewage sludge and biochar were done on day 27,41 and 76 , and from the pots with composted sewage sludge and wetland filters on days 23 and 58 .

The field capacity of the pots was estimated by draining the pot under gravity. All measurement had three replicates. The first experiment consists of the following treatments: blank (soil $+10 \%$ peat), fertilized with sewage sludge (S), fertilized with biochar (B), fertilized with biochar or sludge that was previously amended with concrete $(\mathrm{K})$ at low or high concentration (high $\mathrm{pH}$ treatment with low or high intensity) (BKH, BKL, SKH, SKL), and finally fertilized with biochar or sludge and amended with compost leachate (C) at low or high concentration (low $\mathrm{pH}$ treatment with low or high intensity) $(\mathrm{BCH}, \mathrm{BCL}, \mathrm{SCH}$, SCL).

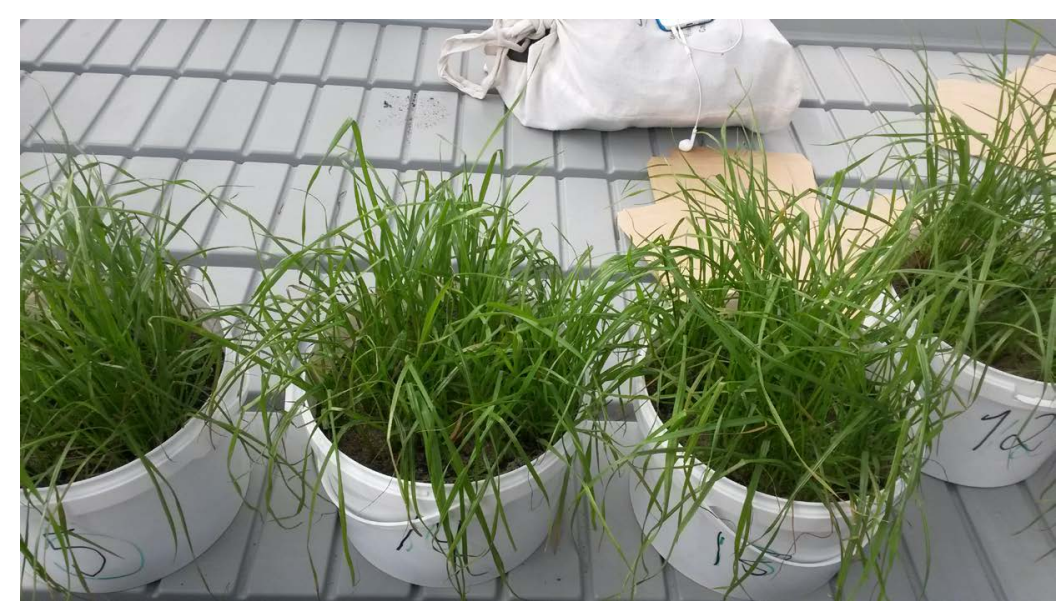

Figure 10. Grass pots. 
The experiment using sludge compost and wetland filter consists of the following treatments: blank (soil $+10 \%$ peat), fertilized with commercial composted sludge (S), fertilized with wetland filter material (W), fertilized with sludge or wetland filter that was previously amended with lime (L) at low or high concentration (high $\mathrm{pH}$ treatment with low or high intensity) (SV or SL), and finally fertilized with sludge or wetland filter and amended with vinegar (V) at low or high concentration (low $\mathrm{pH}$ treatment with low or high intensity) (WV or $\mathrm{WL})$.

DGT passive samplers labelled "Loaded DGT device for As and P" are from [15]. The DGTs were kept cold until used and applied in one-liter plastic pots after the material was kept under water saturation for 47 hours on the average, and at a temperature of 15 degrees $C$. The device was inserted in the pot after making a depression in the soil-waste mixture.

The moisture content in the pots was between field capacity (FC) and 70\% of FC by manually refilling the pots.

$\mathrm{pH}$ in the materials is determined by mixing with $2 \times$ volume distilled water overnight.

Each pot received $300 \mathrm{mg}$ Italian rye grass. The pots were additionally fertilized with $300 \mathrm{mg} \mathrm{N}$ (as $\left.\mathrm{Ca}\left(\mathrm{NO}_{3}\right)_{2}\right)$ and $\mathrm{K}\left(\right.$ as $\left.\mathrm{K}_{2} \mathrm{SO}_{4}\right)$ in the start of the experiment, and an additional $100 \mathrm{mg}$ after each harvest.

The lupin treatments received 6 seeds, 3 of each species, mandelup and luxor.

Loaded DGT devices for As and P were obtained from DGT Research LTD. The materials were soaked in distilled water for 48 hours before installing the DGTs, and the DGTs stayed in the materials for another $48 \mathrm{hrs}$, before added to $65 \% \mathrm{HNO}_{3}$, and subsequently diluted to $10 \%$ before analyzed directly by GCMS. The results were corrected for temperature dependent diffusion according to the manual given for the samplers (DGT Research, undated).

\subsection{Analyses}

\subsubsection{Plants}

Carbon, hydrogen and nitrogen in the plant material was analyzed in an elementar Vario EL KAN20000 with a TCD detector (Ogner et al., 2000). The sample $(5-50 \mathrm{mg})$ is weighed into a tin foil boat. The boat is closes and compressed before introduced into the instrument, and combusted at $950 \mathrm{C}$. The resulting gaes are reduced on a copper column. $\mathrm{C}$ and $\mathrm{H}$ are adsorbed on adsorption columns, $\mathrm{N}$ measures directly. After desorption $\mathrm{C}$ and $\mathrm{H}$ are measured. Dry matter was measured in a TOR0000 drying cabinet at $105 \mathrm{C}$. The sample was dried until constant weight.

\subsubsection{Total Elements}

Total elements in plants and DGTs were analyzed by a ThermoJarell Ash-ICPIRIS HR Duo instrument ICP21100. The sample is blended with digestion acid $\left(72 \% \mathrm{HClO}_{4}+65 \% \mathrm{HNO}_{3}(1+5) \mathrm{v} / \mathrm{v}\right)$ in a teflon bomb. The DGT samples were digested in a $3 \mathrm{ml}$ vial with $10 \% \mathrm{HNO}_{3}$. The sealed bombs are heated in a microwave oven. The heating is controlled so only negligible amounts of gas escape 
through the safety release valve. The bombs are cooled and the sample diluted with water. The elements $\mathrm{Al}, \mathrm{As}, \mathrm{B}, \mathrm{Ba}, \mathrm{Be}, \mathrm{Ca}, \mathrm{Cd}, \mathrm{Co}, \mathrm{Cr}, \mathrm{Cu}, \mathrm{Fe}, \mathrm{Ga}, \mathrm{K}, \mathrm{Li}, \mathrm{Mg}$, $\mathrm{Mn}, \mathrm{Mo}, \mathrm{Na}, \mathrm{Ni}, \mathrm{P}, \mathrm{Pb}, \mathrm{S}, \mathrm{Sc}, \mathrm{Se}, \mathrm{Sr}, \mathrm{Ti}, \mathrm{V}, \mathrm{Y}$ and $\mathrm{Zn}$ are determined by a simultaneous ICP-AES technique by axial or radial viewing of plasma.

\subsubsection{Wetland Filters and Sludge}

The waste and leachate samples were analyzed at the ALS laboratory in Norway, for the parameters total nitrogen, total phosphorus, phosphate, AL extractable phosphorus, total sulphur and the metals $\mathrm{B}, \mathrm{Cu}, \mathrm{K}, \mathrm{Fe}, \mathrm{Mg}, \mathrm{Mn}, \mathrm{Mo}$, and $\mathrm{Zn}$, in addition to $\mathrm{pH}$, TOC and dry matter. Leachate total $\mathrm{P}$ was measured spectrophotometrically according to method EN ISO 6878: 2004, and total $\mathrm{N}$ according to method 11905-1:1998. Sludge and biochar total P and N was measured spectrophotometrically according to methods CSN 72 0116-1 and ISO 11261, respectively. Total $\mathrm{P}$ was calculated from $\mathrm{P}_{2} \mathrm{O}_{5}$. Metals in waste and leachate were measured by ICP method DS259, and in leachate with method DS204.

\section{Results}

There was a significant higher evapotranspiration under the high $\mathrm{pH}$ treatments both for pots with biochar and sludge, for dry matter production, the biochar pots were higher, also the highest for the concrete treatments. The ET was approximately $3 \mathrm{~mm} /$ day in pots with vegetation, and $2 \mathrm{~mm} /$ day in blank with only soil.

The pots with the lupin treatment showed higher yields, this was obvious from observing the pots (Figure 11). The harvest from the pots fertilized with composted sludge and wetland filter (Figure 12) was between $25 \mathrm{~kg} / \mathrm{daa}$ to ca 100 $\mathrm{kg} / \mathrm{daa}$, significantly lower than the harvest of the sludge and biochar pots of 150 $\mathrm{kg} / \mathrm{daa}$ to $300 \mathrm{~kg} / \mathrm{daa}$, due to differences in the length of the growing seasons. The harvest was relatively low both in the sludge and wetland pots, compared to the control with mineral fertilizer (Figure 13). The sludge pots were higher than the wetland pots. There was a tendency to higher dry matter production in the low $\mathrm{pH}$ treatments.

All the pots showed final $\mathrm{pH}$ values between 6 and 7, favorable for plant growth. The $\mathrm{pH}$ in the DGT pots with concrete treatments was slightly higher.

The $\mathrm{P}$ uptake was significantly higher in the pots fertilized with biochar (Figure 14), with a tendency to higher values in the high $\mathrm{pH}$ treatments (BK). In the
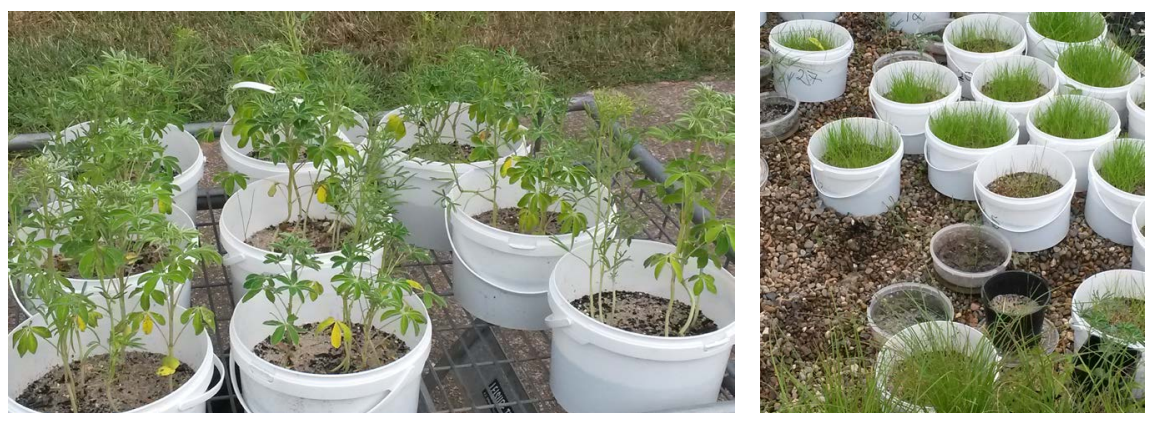

Figure 11. Pots with lupins before seeded with grass (left) and with grass (right). 
Dry matter

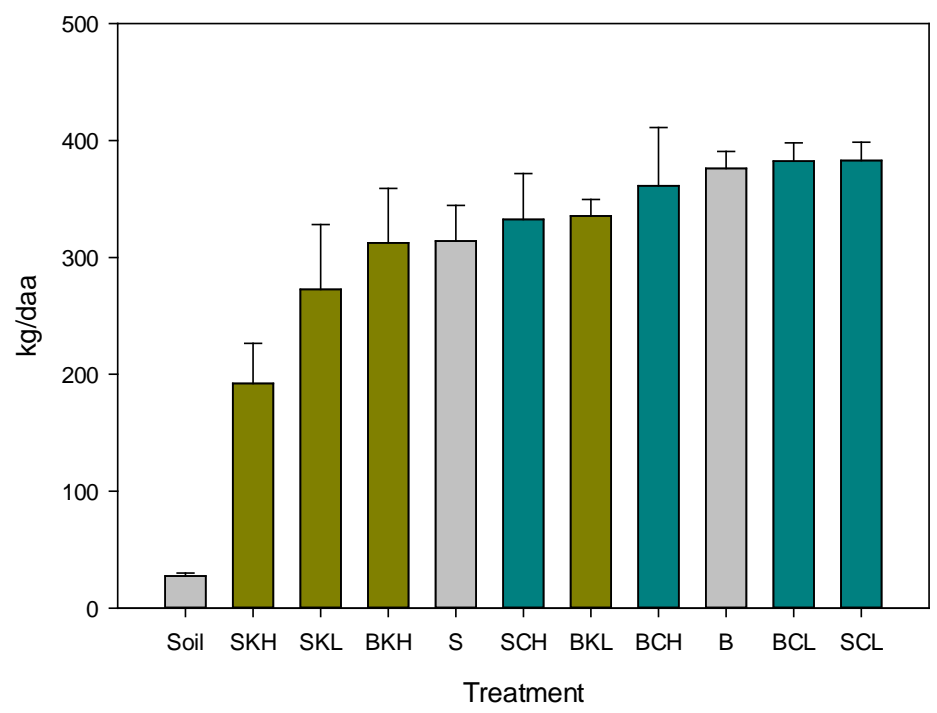

Figure12. Total harvested dry matter. $\mathrm{B}=$ biochar (brown), $\mathrm{S}=$ sludge (blue), $\mathrm{C}=$ low $\mathrm{pH}$ treatment (compost leachate), $\mathrm{K}=$ high $\mathrm{pH}$ treatment (concrete), $\mathrm{H}=$ high, $\mathrm{L}=$ low dosage).

\section{Yield}

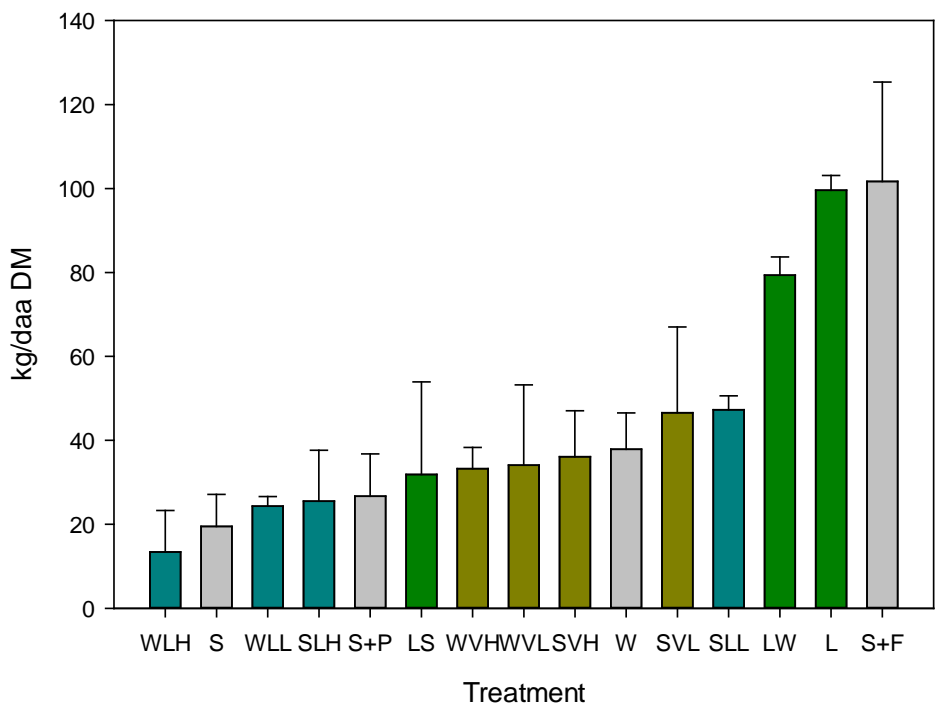

Figure 13. Grass harvest. Treatments: Grey $=$ controls; $S=$ sand + peat (no fertilizer), S + F: sand/peat + mineral fertilizer, $S=$ fertilized with sludge, SVL: sludge + acid low conc., $\mathrm{SVH}=$ sludge acid high, $\mathrm{W}=$ wetland filter, $\mathrm{W}$ treatments as for sludge, $\mathrm{LW}=$ lupins + wetland, $\mathrm{LS}=$ lupin + sludge, $\mathrm{L}=$ lupin + mineral fertilizer (recycled).

sludge pots, there was a tendency to higher values in the low $\mathrm{pH}$ treatments (SC).

The $\mathrm{P}$ uptake was also higher in the pots fertilized with composted sludge (S), and in the low $\mathrm{pH}$ treatment (Figure 15). All pots with the lupin treatment (L) 
$\mathrm{P}$ uptake in grass

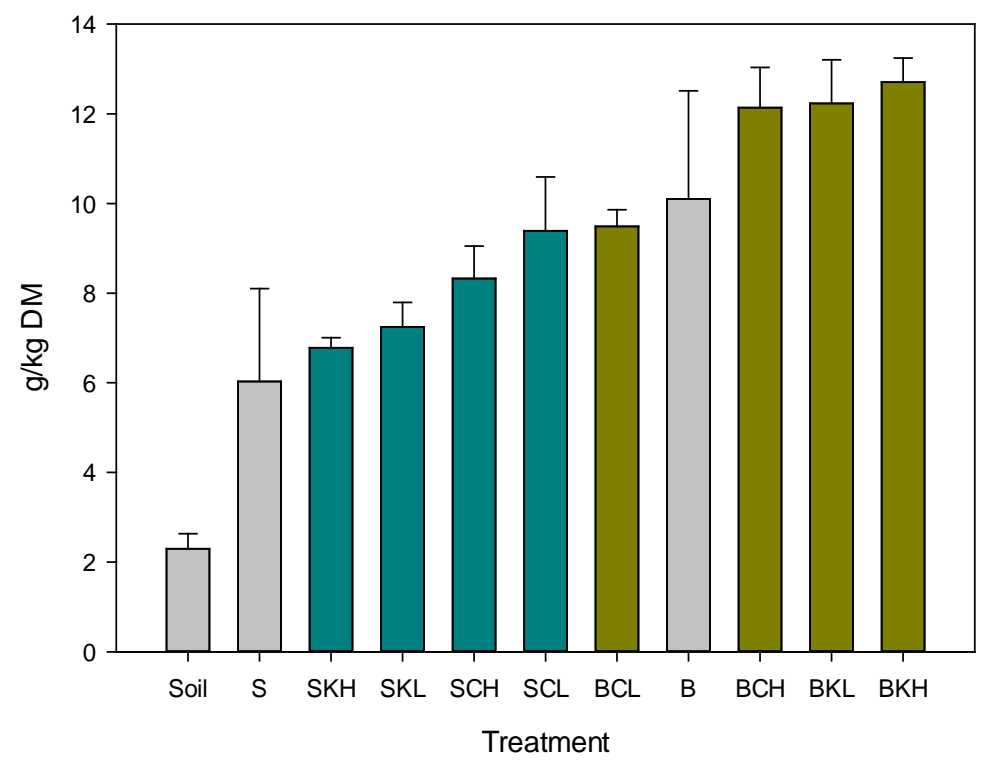

Figure 14. $\mathrm{P}$ uptake in grass from sludge and biochar. $\mathrm{B}=$ biochar (brown), $\mathrm{S}=$ sludge (blue), $\mathrm{C}=$ low $\mathrm{pH}$ treatment (compost leachate), $\mathrm{K}=$ high $\mathrm{pH}$ treatment (concrete), $\mathrm{H}=$ high, $\mathrm{L}=$ low dosage, grey = control.

\section{$P$ uptake in grass}

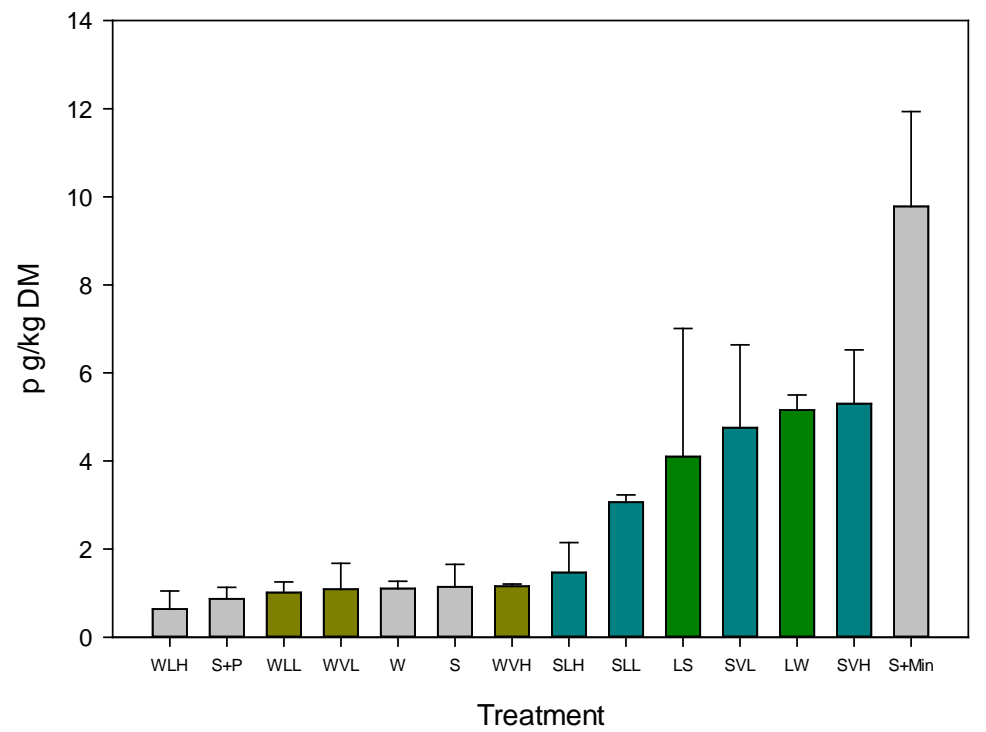

Figure 15. P uptake in grass from sludge and wetland filters. Treatments: Controls = grey; $\mathrm{S}+\mathrm{P}=$ sand + peat (no fertilizer) $\mathrm{S}+\mathrm{Min}=$ sand $/$ peat + mineral fertilizer, $\mathrm{S}=$ composted sludge (brown), SVL: sludge + acid low conc., $\mathrm{SVH}=$ sludge acid high, $\mathrm{W}=$ wetland filter (blue), $\mathrm{W}$ treatments as for sludge, $\mathrm{L}=$ lupins (green), LW = lupins + wetland, LS = lupin + sludge, $\mathrm{L}=$ lupin (recycled).

show relatively high $\mathrm{P}$ uptake. The $\mathrm{P}$ uptake in the Australian experiment was lower that the uptake in the Norwegian experiment ( $6 \mathrm{~g}$ to $12 \mathrm{~g}$ ). The uptake of $\mathrm{P}$ 


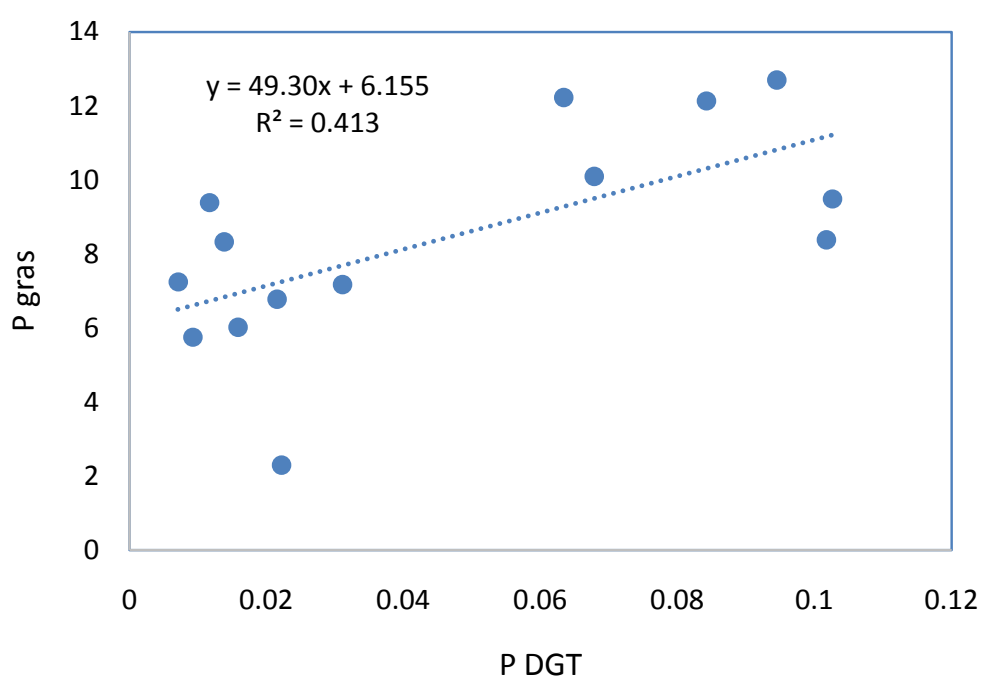

Figure 16. Correlation of the P concentrations in the DGTs and the grass.

both in grass and in the DGTs is clearly and significantly higher in the posttreated by lupins.

Figure 16 shows a significant correlation between the $\mathrm{P}$ uptake measured in the DGTs and in the grass, with a correlation coefficient of $R^{2}=0.41$. $P$ uptake as measured by the DGT is further correlated with $\mathrm{K}$, Si while Fe, and uncorrelated with $\mathrm{Ni}, \mathrm{Cu}$ and $\mathrm{Ca}$.

\section{Conclusions}

- The mean irrigation in the experiment was between 3 to $7 \mathrm{~mm} /$ day, the evapotranspiration between 2 and $3 \mathrm{~mm}$ /day in pots without and with vegetation;

- Grass P uptake was significantly higher in pots fertilized by biochar compared to pots fertilized by sewage sludge;

- Biochar responded better after $\mathrm{pH}$ treatment than sewage sludge;

- P uptake from composted sewage sludge was higher than from wastewater filter material;

- The sludge responded better whit acidic treatment;

- The wetland filter did not respond to $\mathrm{pH}$ treatment;

- The lupin treatment showed a high uptake of $\mathrm{P}$ almost comparable to mineral fertilizer;

- The DGT samples produced approximately the same results as the direct measurements of the grass, although the correlation was not perfect;

- If phosphorus uptake is the priority, organic waste benefits from being turned into biochar before used as fertilizer.

\section{Acknowledgements}

Thanks are due to Alena for helping with carrying out the experiments, to Jeff Lennox at Australian Native Landscapes (ANL) PTY LTD for supplying composted sewage sludge, and to Jonathan Clements, Senior Lupin Breeder, Grains 
Industry, Department of Agriculture and Food, Western Australia for providing lupin seeds, and Professor H. Lambers for information on lupins.

\section{References}

[1] Lambers, H., et al. (2006) Root Structure and Functioning for Efficient Acquisition of Phosphorous: Matching Morphological and Physiological Traits. Annals of botany, 98, 693-716. https://doi.org/10.1093/aob/mcl114

[2] Hyland, C., et al. (2005) Phosphorous Basics-The Phosphorous Cycle. Agronomy Fact Sheet Series 12, Cornell University, UK.

[3] Lambers, H., Chapin III, F.S. and Pons, T.L. (1998) Plant Physiological Ecology. Springer, New York. https://doi.org/10.1007/978-1-4757-2855-2

[4] Wang, Q. and Li, Y. (2010) Phosphorous Adsorption and Desorption Behavior on Sediments of Different Origins. Journal of Soils and Sediments, 10, 1159-1173. https://doi.org/10.1007/s11368-010-0211-9

[5] Braskerud, B.C., Tonderski, K.S., Wedding, B., Bakke, R., Blankenberg, A.-G.B., Ulén, B. and Koskiaho, J. (2005) Can Constructed Wetlands Reduce the Diffuse Phosphorous Loads to Eutrophic Water in Cold Temperature Regions? Journal of Environmental Quality, 34, 2145-2155. https://doi.org/10.2134/jeq2004.0466

[6] Jenssen, P.D., et al. (2010) Filter Bed Systems Treating Domestic Wastewater in the Nordic Countries-Performance and Reuse of Filter Media. Ecological Engineering, 36, 1651-1659. https://doi.org/10.1016/j.ecoleng.2010.07.004

[7] Kvarnstrøm, M.E., Morell, C.A.L. and Krogstad, T. (2004) Plant-Availability of Phosphorous in Filter Substrates Derived from Small-Scale Wastewater Treatment Systems. Ecological Engineering, 22, 1-15. https://doi.org/10.1016/j.ecoleng.2003.12.005

[8] Øgaard, A.F. (1996) Effect of Fresh and Composted Cattle Manure on Phosphate Retention in Soil. Acta Agriculturae Scandinavica, Section B-Soil \& Plant Science, 46, 98-105.

[9] Reddy, K.R., et al. (2005) Biogeochemistry of Phosphorous in Wetlands. In: Sims and Sharpley, Eds., Phosphorous: Agriculture and the Environment, American Society of Agronomy, Inc., Wisconsin, 263-316.

[10] Mason, S.D., et al. (2013) Soil Test Measures of Available P (Colwell, Resin and DGT) Compared with Plant P Uptake Using Isotope Dilution. Plant Soil, 373, 711722. https://doi.org/10.1007/s11104-013-1833-7

[11] Six, L. (2014) Testing Phosphorous Availability for Maize with DGT in Weathered Soils Amended with Organic Materials. Plant Soil, 376, 177-192.

https://doi.org/10.1007/s11104-013-1947-y

[12] Santner, J. (2012) High-Resolution Chemical Imaging of Labile Phosphorous in the Rizosphere of Brassica napus L. Cultivars. Environmental and Experimental Botany, 77, 219-226. https://doi.org/10.1016/j.envexpbot.2011.11.026

[13] Eggen, T. and Røyset, O.U. (2008) Testing of DGT to Measure Plant Available and Mobilization of P from Agricultural Soil-Prephase Project. In Norwegian. Fact info. The soil and Peat Foundation. 20 p.

[14] Kahiluoto, H., et al. (2015) Phosphorus in Manure and Sewage Sludge More Recyclable than in Soluble Inorganic Fertilizer. Environmental Science \& Technology, 49, 2115-2122. https://doi.org/10.1021/es503387y

[15] DGT Research, Undated. http://www.dgtresearch.com/guides-to-using-dgt 
Submit or recommend next manuscript to SCIRP and we will provide best service for you:

Accepting pre-submission inquiries through Email, Facebook, LinkedIn, Twitter, etc. A wide selection of journals (inclusive of 9 subjects, more than 200 journals)

Providing 24-hour high-quality service

User-friendly online submission system

Fair and swift peer-review system

Efficient typesetting and proofreading procedure

Display of the result of downloads and visits, as well as the number of cited articles Maximum dissemination of your research work

Submit your manuscript at: http://papersubmission.scirp.org/

Or contact jep@scirp.org 